\title{
Political Myth and Political Glory: Shaping Media Reality
}

\author{
Maria Shteynman \\ PhD (Philology), Associate Professor at the Chair of Communication Studies and Public Affairs, \\ Department of History, Political Science and Law, Russian State University for the Humanities \\ Address: Miusskaya square, 6, GSP-3, Moscow, Russian Federation 125993 \\ E-mail: philology@mail.ru
}

\begin{abstract}
Today we cannot but notice the sequence of the considerable changes in the present-day social and cultural order through the obvious process of its invasion by certain semiotic constructs, possibly described as political myths, and nearly all of them closely connected with the issue of past/present/future glory. This glory could be lost (e.g., the collapse of the USSR), or gained anew (e.g., the joining of Crimea in 2014). The concepts of glory and victory in Russian political discourse are bound up with each other so closely that it is difficult to divide them. Besides, glory and victory are being gradually possessed by the establishment. At the same time, political myths are the means and the aim of this process. Myth comes forward as a universal code, and moreover, as a universal social-cultural matrix which contains patterns of ethics that are to be installed into the society. Besides, myth is a structure based upon the category of shaping the reality in which people may believe, not the category of belief. In the sphere of the media, myth broadcasts itself mainly through memes, using them both as instruments and as a certain communication channel. The structure of a meme is semiotic, while there is still a communicative difference between a meme and a myth. The idea of political glory is closely connected with the sphere of myth and with the concepts of time and space. This kind of integration makes up what Bakhtin called a "chronotope." Three main myths of historical glory in present-day political discourse can be distinguished: the myth of Byzantium and the so-called "The Fifth Empire," the myth of the "Polite People," and the myth of "Panfilov's Twenty-Eight."
\end{abstract}

Keywords: political myth, mythologem, mythology, chronotope, meme, media reality, history, ideology

\section{Introduction}

We face different communicative trends today in political discourse, especially in the sphere of the media, the most important and ambiguous one being the question of political myth. A considerable number of attitudes to the concept of political myth exist, such as in the context of narrative (H. Tudor, Ch. Flood, Ch. Bottici), through the prism of a connection with language and symbol (E. Cassirer, N. Frye), and from the viewpoint of semiology (R. Barthes). At present, the most relevant approach to the political myth needs to combine both the symbolic and semiotic aspects. These seem to provide most efficient instruments to deconstruct ideologically engaged and politically motivated statements in the social and cultural spheres. Then, a working definition would be "political myth is a

(C) Maria Shteynman, 2016

(c) Centre for Fundamental Sociology, 2016

DOI: 10.17323/1728-192X-2016-4-96-113 
special kind of ideologically transfigured sign that has the potential of transforming the sociocultural reality (or perhaps even create an alternative one)."

In a period less than of a year, the terms "myth" and "political myth" have become a core point in the heated debate in which nearly all levels of society from scientists (the head of the State Archive of the Russian Federation Sergey Mironenko) to ministers (the Minister of Culture Vladimir Medinsky) appear to be involved in. What is even more significant is that this issue of political myth obviously has been raised in connection with the matter of political glory and the problem of "sacred" history and "sacred" victory. As a result, the category of science and historic facts are de facto possessed by and included in the sphere of politics. For instance, J. Lull calls such phenomenon "patriotic symbolism" (Lull, 2008: 21).

In its turn, the discussion mostly took place in the media, from mass media to social media. According to Lull, the ideas circulate in society via modern communicative technology (ibid.: 17). It is then possible to assume that political myth is a special way of shaping media reality, or, as McLuhan put it, political myth is the medium and the message at one time.

In essence, the main foci of this work will be to place the conception of political glory into the framework of cultural time and space (or M. Bakhtin's chronotope); to fix the boundaries of political myth; to observe the phenomenon of the meme as a communicative instrument of myth in order to shape media reality; and to track the messages and the structure of three main political myths, those of the Byzantium Empire, the "Polite People," and the myth of "Panfilov's Twenty-Eight."

\section{Myth and Other Key Concepts of Political Discourse Analysis}

The concept of political glory is closely connected with the sphere of the myth by means of the concepts of time and space. The "inseparability of space and time" of Bakhtin's chronotope apparently could be applied not only to the field of literature but to the field of culture as well. ${ }^{1}$ In his Forms of Time and Chronotope in the Novel he focuses on a historical inversion when mythological thinking "locates such categories as purpose, ideal, justice, perfection, the harmonious condition of man and society in the past" (Bakhtin, 2004: 147). That is why "the future is here portrayed as something out of the past" (ibid.: 158), especially out of a heroic or Golden Age.

Hence, the special role of the past and the future lead us to the reduction of the category of the present. The present is nothing but an intermediate locus between the heroic past and the blissful, but vague and uncertain future. The future itself is not "homogeneous with the present and the past... it is somehow empty and fragmented-since everything affirmative, ideal, obligatory, desired has been shifted, via the inversion, into the past" (ibid.: 147).

1. Chronotope is considered from different angles in: Nielsen, 2002; Bemong et al., 2010; Flanagan, 2009; Cohen, 1998; and Sungurov, 2003. 
Today, the category of historic as well as political glory obviously belongs to the past, whereas the past itself has shifted from the field of scientific facts into the field of political myth, which Cassirer would have called the myth of the state.

It is essential to define the frames of the political myth. There is an established tradition of understanding political myth in terms of narration and plot. Nevertheless, myth, and political myth as well, is more of a sign than a narrative. Another important point is the creativeness of myth.

Henry Tudor considers political myth as a feature of advanced societies (Tudor, 1973: 14). This is why some authors adhered to the concept that political myth belongs to the field of history. The considerable changes in the perception of political myth appeared in the works of Georges Sorel where he elaborates that "the hallmark of the myth" that "provides a vision of the future which makes crude but practical sense of present" (ibid.: 15). Tudor himself suggests the attitude to myth as an "interpretation of what the myth-maker (rightly or wrongly) takes to be hard fact" (ibid.: 17).

Tudor's conception of political myth has three main points: the ability to be believed in; a grip with reality; and being "a story, that is a narrative of events in dramatic form" (ibid.: 16).

Paradoxically enough, Tudor comes to the conclusion that there is "nothing distinctive about the political myth" but the "subject matter" (ibid.: 17). At the same time, Christopher Flood (Flood, 2013) distinguishes two aspects of myth, those of "sacred" and "political." However, this division does not look convincing as it is based upon the bare communicative function of myth as connected with the field of its usage.

Reflecting on the term of myth, Flood combines the terms "narrative" and a "mode of thought" (Flood, 2013: 27). It would appear that he understands myth in a narrow mode, putting it into the ideologically marked field of political narrative (ibid.: 46). However, the author later tries to combine the concepts of belief, ideology, and myth in one working definition when he writes: "An ideologically marked narrative which purports to give a true account of a set of past, present, or predicted political events and which is accepted as valid in its essentials by a social group" (ibid.: 44). Flood also defines mythopoetic political discourse with almost the same words. To him, then, myth is equivalent to "mythopoetic discourse."

The issue of political discourse is based upon several key concepts, one of the most important belonging to Norman Fairclough. He stresses the connection between discourse and different social practices such as the political, the cultural, and so on. Another key idea is that of "the dialectual relationships between discourse (including language but also other forms of semiosis) and other elements of social practices" (Fairclough, 2001: 231-242).

Political discourse as well as Critical Discourse Analysis today focuses upon communication in its variety including the institutional, media, and the political. According to Ruth Wodak, the main aim of Critical Discourse is "to unmask ideologically permeated and often obscured structures of power, political control and dominance" (Wodak, 
Ruldof, Liebhart, 1999: 8). This goal is obviously based upon Barthes's approach to myth as an ideological construction.

Meanwhile, discourse as such is understood as "a form of social practice." This is why any kind of discourse is affected by different political and social contexts and, in their turn, different discourses may have a considerable influence upon different dimensions of social and political reality (ibid.: 8 ).

In her turn, Ciara Bottici (Bottici, 2007) stresses the connection between philosophy and political as well as non-political myth. According to her, one of the most important features is that "myth has to be open to a process of continual retelling," but at the same time myth, being narrative, stimulates people to act (ibid.: 183). In its turn, the retelling of the myth is based upon "mythologem" (ibid.: 127) as the building material of myth. Therefore, he existence of mythologemes gives myth a chance to become adjusted to contemporary changes in social, cultural, and political reality.

Secondly, the theory of contemporary political myth is largely based on Ernst Cassirer's works on language, myth, and state (Cassirer, 1953, 1973). In his Language and Myth, Cassirer stresses the connection between myth and the symbol. For him, one of the most important features of myth is creating a reality; he writes that "myth, art, language and science appear as symbols; not in the sense of mere figures which refer to some given reality by means of suggestion and allegorical renderings, but in the sense of forces each of which produces and posits a world of its own" (Cassirer, 1953: 76).

Perhaps that is exactly why Ernst Cassirer spoke about "the appearance of a new power: the power of mythical thought" in his Myth of the State. This kind of thought becomes increasingly important in crisis situations. Cassirer draws a special distinction between the sphere of society where stability can exist, and politics, where the equilibrium is utterly unstable. This is why he says that "in all critical moments of man's social life, the rational forces that resist the rise of the old mythical conceptions are no longer sure of themselves. In these moments the time for myth has come again" (Cassirer, 1973: 280). Cassirer speaks about it with distinctly negative emotions, using expressions such as "the demonic mythical power." Moreover, his views here coincide with those of Roland Barthes, expressed eleven years later in Myth Today (Barthes, 1991).

It is highly significant that even Northrop Frye (1982) is of the same view, underlining this idea in The Great Code; Frye writes that "myth is a form of imaginative and creative thinking, and is therefore autonomous" (ibid.: 35). Frye also sees the bonds between myth and history, as mythology "contains a great deal of legendary and traditional history, it also helps to foster the growth of what we should call history" (ibid.: 34).

Thirdly, according to Roland Barthes (1991), myth is a sign that has already been transfigured and even corrupted by the current ideology. In his work Myth Today, Barthes stresses the political component of the process of mythologization. Thus, the whole reality is penetrated by myths, that are, in their turn, political matrixes. The whole process would have been impossible without the media. Moreover, the media can be considered as a primal condition of the existence of any myth. 
Barthes's attitude to the phenomenon of political myth is based upon both semiology and post-structuralism. The idea of deconstruction provides a steady methodological instrument. In other words, political myth can be detected and deconstructed by means of semiotics. According to Barthes, myth is based upon the tri-dimensional pattern, consisting of the signifier, the signified, and the myth. He argues that myth is "a peculiar system," as it is "constructed from a semiological chain which existed before it: it is a second-order semiological system" (Barthes, 1991: 111). This second-order system appears because myth needs to build its own system in order to transmit its own meanings. Myth itself is a sign both transfigured and transformed by ideology. To put it another way, myth is an ideologically corrupted sign and, at the same time, a special system of such signs.

Barthes's concept seems to be most suitable on two grounds. First, Barthes's myth correlates with Frye's "great code" as a universal key to the interpretation of historic events. On the other hand, understanding myth as a sign could explain the fact that a semiological system is gradually becoming a background for memes (as will be shown below). Finally, the ideas of Barthes, Cassirer, and Frye have one common feature: myth can create a new alternative reality.

\section{Features of the Present-Day Russian Political Myth}

Let us try to give the description of today's Russian political myth. Firstly, it is based upon the main cultural models, and these models could be understood in terms of nuclear elements, or semiotic mediations of time and space according to Mikhail Bakhtin's theory of the chronotope. Secondly, these based components need some narrative details, or mythologems, which have their source either in traditional culture or in postmodern mass-culture. Thirdly, political myth uses the new media as a communication channel for the viral expansion of memes.

It is highly significant that the meme is closely connected with belief and ideas. Memes have a rather curious structure in that they are semiotic, narrative, and digital at the same time. Of the myriad of memes, one of the most interesting examples is the "Hymn to Polite People."

As the process of establishing of a myth begins, the important point is to use the sphere of mass culture as a special communication field. In the refrain of "Hymn to Polite People" (Kalinin, Khokhryakova, 2014), the whole vector of the temporal frame has an irregular direction, that is, not from the Present to the Future, but from the Present to the Past. Thus, the idea of any kind of future life in Russia is either absent or replaced with the "sacred past."

Then what is the mechanism of the dissemination of a myth? In the sphere of the media, myth broadcasts itself mainly through memes.

The meme as a cultural phenomenon of the $21^{\text {st }}$ century belongs to the digital media reality that tends to form its own ideological network. While the similarity between myth and meme is obvious, especially in the context of the attitudes of Cassirer and Barthes, both myth and the meme have the power of shaping a society. Still, there is a serious 
difference. Though the meme belongs to the sphere of beliefs, just as myth does, it has a different way of functioning and different communicative modes. Lynch says that "beliefs affect retransmission in so many ways that they set off a colorful, unplanned growth race among diverse 'epidemics' of ideas. Actively contagious ideas are now called memes" (Lynch, 1996: 5). Memes are most effective in a so-called "motivation mode," implying the situation when "the larger the number of people who want to hold a specific idea, and the more strongly they want it, the greater will be its motivational advantage" (ibid.: 9).

It is highly significant that the meme is closely connected with belief. As Lynch (1996) stresses in his book, "like a software virus in a computer network ... thought contagions proliferate by effectively 'programming' for their own retransmission" and "beliefs affect retransmission in so many ways" (ibid.: 5 ). In other words, the meme needs to be the object of belief. Lynch also gives the following description, writing that "actively contagious ideas are now called memes." Memes have rather curious structure; it is semiotic, narrative, and digital at the same time. It follows that present-day myths that form a kind of the mythosphere also have meme-like features.

Therefore, memes as "contagious ideas" resemble "demonic mythical power," since, according to Cassirer, "in desperate situations, man will always have recourse to desperate means-and our present-day political myths have been such desperate means (Cassirer, 1973: 279).

The fundamental difference between them, though, is the ability to create a secondary reality. Myth has the capacity not just to influence the human mind, but also to build up an elaborated system of values which is easy to believe in. Memes, in their turn, may serve as a kind of building block for this system of values. Such kinds of construction materials also provide the system with a perfect communication channel.

In the period of 2008-2016, three such myths appeared: the Myth of the Byzantium Empire, the myth of "Polite People," and the myth of "Panfilov's Twenty-Eight."

All of these are included into the greater myth of the Sacred Empire, and are disseminated through the meme of "spiritual bonds." This meme came to life when President V. V. Putin, in his annual 2012 address to the Federal Assembly, mentioned that Russia is facing "an obvious deficit of spiritual bonds such as charity, compassion, support, and mutual aid" - in other words, a lack of "what for all time has made us stronger and more powerful, what we have always been proud of" (Putin, 2012). From this point forward, the expression "spiritual bonds" has become a kind of Internet meme in Russian social media. Moreover, the area of its usage has considerably widened since then. For instance, a Google search for "духовные скрепы” (spiritual bonds in Russian) gives more than 348 , 000 results. The term "spiritual bonds" has become a part of the political, cultural, and social discourse in Russia. It must be noted that these "spiritual bonds" are first and foremost based upon the idea of the sacredness of the past. 


\section{The Three Main Myths of Historical Glory in Russian Political Discourse Today}

\section{The Myth of the Sacred Empire}

The myth of the Sacred Empire is surely the other name for the The Russian Empire in a contemporary cultural paradigm. It is one of the most powerful concepts in present-day political discourse. In 2012, this idea was predicted in Joe Right's film Anna Karenina, which begins with the shot of an enormous dark-red drop-curtain embroidered with the golden words "Imperial Russia." This attitude provoked a heated discussion in Russian social media as a considerable number of the audience declared themselves "offended" by the director's attitude of Russia as a shabby theatre. Regardless of the obvious fact that Joe Right had the allusion to Shakespeare's "All the world's a stage" in mind, he was accused in "being hostile to the great Russian culture" (Shteynman, 2014: 292).

Actually, the hostility of a significant part of the Russian audience has another explanation, that of a kind of patriotic jealousy. People have a non-verbal but distinct feeling that the concept of the "Russian Empire" belongs to their country, and personally to them. No foreign interpretation should be allowed. Such an idea is closely connected with the process of the "sacralization of the Russian Past."

The process started in 2008 when a well-known docu-fantasy The Fall of Empire: The Lesson of Byzantium appeared. The author of the film is the Archimandrite Tikhon Shevkunov, the Superior of the Sretensky Monastery in Moscow. The script is based upon the well-known and widely-used opposition between the East and the West, where the East is the center of culture, and the West is an accumulation of chaos and destruction. The film's author writes that "one can only imagine-indeed, history records it as suchhow crude, ignorant Scandinavians, Germans, Franks, and Anglo-Saxons, whose chief occupation at the time was primitive sacking and pillage, after arriving from some town like Paris or London (which had populations of some tens of thousands) to this megalopolis of millions, a city of enlightened citizens, scholars, and elegantly dressed youths crowding imperial universities, dreamt of only one thing: invading and robbing, robbing and invading" (Shevkunov, 2008). Moreover, the "barbaric West became the civilized West only after it had taken over, stolen, destroyed, and swallowed up the Byzantine Empire" (ibid.).

This idea of glory and grandeur is closely connected with the ideas of sacredness. The author of the film claims that "the greatest treasure of Byzantium was God." According to him, Russia is the spiritual successor to Byzantium. The description of this revelation definitely shifts the emphasis from Byzantium to Russia, and specifically to Prince Vladimir: "Prince Vladimir's ambassadors experienced only in Byzantium that a true relationship between God and man exists; that it is possible for us to have living contact with another world" (ibid.).

The ideological intention of the film is clear, which is to stress the idea of the likenesses between Byzantium and Russia by drawing a number of quasi-historical parallels between them. However, the main intention is much more important and less obvious. It 
is to build up a myth of the common history, and thus to equate Russia with Byzantium as the same Sacred Empire.

The imperial ideas in present-day Russia have been further developed in the area of political discourse of "radical" conservatives such as A. Prokhanov, who declared "the rise of the Fifth Empire" (Budaragin, 2012), since Stalin's Soviet Union was the Fourth Empire, in his opinion.

The eighth bike-show, organized by Alexander Zaldostanov (also known as the Surgeon) and his bike club the Night Wolves, represented the institutionalizing of this concept. In 2016, his bike show was entitled "The Fifth Empire." The head of the Night Wolves stressed two important points, those of the connection between the Soviet Union and present-day Russia, and the connection between the past and the future. According to him, "Stalin era attracts by heroes. People believed in dream, believed in idea and were ready to be killed and kill for it" (Dremova, 2016).

The main message of the show was built upon the opposition between "friends" and "foes," where "friends" were represented by quasi-Soviet citizens, and the appearance of "foes" included a distorted Statue of Liberty and dancing skulls.

Being the guest of honor at the show, A. Prokhanov gave the clue to the whole event: "There is a lot of fire, light, music, power, dancing. This is what happens in a temple. In the temple that was built by the Surgeon the new reality is coming to life. Because the Fifth Empire is our present-day Russia. Our aboriginal imperial identity is waking up in the consciousness of the young audience. The Surgeon is a magician, sorcerer, wizard!" (Meduza, 2016). Prokhanov's words formed a comprehensive picture of the hidden messages of the show: this "new reality" is a political myth that has the clear characteristics of a neo-religious cult.

The whole case clearly illustrates the passage from The Power and Society, where the authors say that "group consciousness initially increases with conflict with other groups with equal or higher degrees of consciousness. Such conflict strengthens existing patterns of solidarity: the 'we' becomes crystallized and important as over against a blatant 'they.' The most familiar example is the increase of patriotism in wartime, involving not merely a strengthening of identifications, but of interests, faith, and loyalties as well" (Lasswell, Kaplan, 1950: 46).

\section{The Myth of Polite People}

The Myth of Polite People is one of the most interesting examples of the process when myths transmit the new version of political reality by means of memes. The myth about the "Polite People in Crimea" provides us with one of the most relevant examples.

Actually, this expression consists of two different groups, the Polite People and the Little Green Men. The former is mostly used in Russian political discourse, whereas the latter can be found in the mass media outside of Russia.

The meme "Polite People" appeared on February 24, 2014, in Boris Rogozin's report which was one of the first reports of the situation, and titled "Polite People Blockaded 
Two Airports in Crimea." There was a sentence in the report where "a security officer said: "They politely asked me to leave"' (Rozhin, 2014). Then, the first appearance of the expression was clearly occasional. Later, though, several journalists and bloggers gave a different version of the meme's origin: "According to a popular blogger Ilya Varlamov, the term 'polite men' was invented by spin doctors who arrived in Crimea from Moscow" (Shevchenko, 2014).

Irregardless, the term "Polite People" seemed to be extremely useful for the authorities since it helped to build a positive image of ostensibly-unknown masked and unmarked soldiers who were wearing green army uniforms and wielding Russian military weapons. The adjective "polite" characterized both their manner and their positive intention. In order to enforce the myth, a new meme was added. This time, it was a popular networking image of a cat ("kotik"). Many users of the most popular Russian social network VKontakte posted photos depicting Crimean residents, especially children and young girls, embracing the solders as well as military people holding a big and fluffy ginger cat. The main goal was to create the image of the solders as peaceful, but powerful, troops.

The institutionalization of the meme was completed in April, 2014, when the Defence Minister Sergei Shoigu added a final touch to the glossy image of the Polite People by saying that it is impossible to find a black cat in a black room, "especially if the cat is smart, bold, and polite" (Skibina, 2014).

The process of establishing of a myth had just begun. The next step was to use the sphere of mass culture as a special communication field. In April, Anton Gubankov, the Head of the Culture Department of the Russian Ministry of Defense, wrote a poem in a night, "being inspired by the return of Crimea" (Kalinin, Khokhryakova, 2014). It was no wonder that several days later, the Russian Army Choir released a song glorifying the military troops in unmarked uniforms. By this time, though, the Polite People were obviously marked as belonging to Russia. The performance of the "Polite People Song" appeared on the official YouTube site, and the video received 100,000 hits per day.

A year later, on May 6, 2015, the first monument honoring the "Polite People" had been erected in the Far Eastern city of Belogorsk (Sindelar, 2015). The monument is based on the image of a solder passing a ginger cat to a teenager, and was taken by TASS photographer, Alexandr Ryumin.

What is the hidden meaning of the Polite People? To answer this question, it is necessary to analyze the text of the "Hymn to Polite People." From beginning, the entire song is written in accordance with the folklore genre of incantation chanting. The goal of any incantation is to transform reality, and Anton Gubankov's poem is no exception. ${ }^{2}$

\footnotetext{
2. Вежливо люди с вежливым взглядом

Вежливо смотрят, вежливо просят.

Просто стоят они вежливо рядом,

Просто оружие вежливо носят.
}

Припев:

Все будет хорошо, отлично будет!

Победы предков нас вперед зовут. 
The song is as follows:

These polite people with polite glances

Staring politely, asking politely

Just standing politely so close to you

Just carrying politely their big guns

\section{Chorus:}

Everything will be all right, really fine

Our sires' victories are calling us ahead

Long live, our country, and your polite people

Keep safe your peace, your honor and your fame

Polite are the helmets, polite are the faces

Polite are the steel vehicles as well

Polite is the capital composing bylinas ${ }^{3}$

About the people that are most polite

Polite are the distances, polite is the sky

Polite is the wind waving the banner

Polite is the Motherland with bread-and-salt-welcome

The triumph ahead us predicts happiness. ${ }^{4}$

The text has all the constitutive features of an authentic incantation, those of the commencement, the culmination, and the denouement. It also has a special refrain, the main function being a "holdfast," a kind of hook to plant the message into the audience's minds.

The message is based upon the spatial/temporal frame by M. Bakhtin. In his Forms of Time and Chronotope in the Novel, he gives several models, one of which is so-called "Dream Time" (Bakhtin, 2000: 76) that is the Sacred Past. There is exactly the same model in the refrain of the "Hymn to Polite People"; it is "Our sires' victories are calling us

\footnotetext{
Живи, страна, а вежливые люди

Отчизны честь и славу сберегут.

Вежливы каски, вежливы лица, Вежливы даже стальные машины.

Вежлива наша родная столица,

О вежливых людях слагая былины.

В вежливых далях вежливо небо, Вежливо ветер знамя полощет. Вежлива Родина вежливым хлебом Ждут нас победы и счастье пророчат 3. Bylina-Russian epic.

4. Translated by me.
} 
ahead." This means that the whole vector of temporal frame is not from the Past to the Future, but from the Present to the Past. The idea of a future life in Russia is either absent or replaced with the "sacred past."

What about the spatial frame? Again, it is clear that the incantation tries to turn the whole country from the space of present-day Russia to imperial/Soviet Russia. The marker of such an intention is the line "Polite is the capital composing bylinas." A "bylina" is one of the genres of the Russian epic, depicting the heroic exploits of Russian warriors. The concept of the Sacred Past is then completed with the concept of the Sacred Space inhabited by heroes, here represented by the Polite People.

The word "bylina" is highly significant in this song as it is an unintended cultural reference familiar to any Soviet citizen born before 1975. The verse implies another song, that of "Budyonny's March" ${ }^{5}$, with lyrics by Anatoly D'Actil, and music by Daniil and Dmitry Pokrass. The March was written and composed in 1920. The popularity of the song among Red Army soldiers was so great that, in later years, it was included in numerous collections of folklore songs.

From the very beginning of the "March," the similarity of the songs becomes obvious:

We are the cavalrymen of the Red Army,

and the stories are told

about us

by the eloquent bylinniks (narrators). ${ }^{6}$

The refrain is equally interesting: "We are the heroes, all of us, and the whole life of us the just struggle." Thus, the word "bylinnik" unites the two songs and the two historic loci of the heroic past and the heroic present. Therefore, both the Red cavalrymen and the Polite People belong to the concept of epic heroes, and, hence, to the epic time frame.

In other words, the "Hymn to Polite People" represents a profound gap between the spheres of the Past, Present, and Future dimensions in the Russian mentality. O. Matveeva and I. Melik-Gaikazyan have recently undertaken a research project concerning the model of time in Russian culture (2005: 164) and they have come to a rather pessimistic conclusion. According to the research, there is no connection between the different spheres of time in the mental background in Russia and, moreover, the concept of the Present as such seems to be highly insignificant.

Thus, in present-day Russian political discourse, the myth of the Polite People is based upon the epic chronotope where the Present is totally absent, and the Future is re-addressed to the heroic, dream-like Past.

\footnotetext{
5. In the original - «Марш Буденного».

6. Мы-красные кавалеристы

и про нас

былинники речистые

ведут рассказ.
} 


\section{The Myth of Panfilov's Twenty-Eight}

On April, 20, 2015, in his interview to the Kommersant the head of the State Archive of the Russian Federation, Sergey Mironenko, argued that historical facts can hardly be falsified because it is always possible to check the archives. He also stressed the point that history is not the same as "political games" (Khamraev, 2016). It is most noteworthy that one of the key issues of the interview is the case of the " 28 soldiers of General Panfilov." According to the historian, the legend was fabricated by a reporter named Koroteev and a literary editor named Krivitsky for the Krasnaya Zvezda newspaper. The reaction of the journalist in this interview is highly significant. He simply denies the accusation of invention, saying "I have been considering them as heroes from my childhood and I don't want to change my mind" (Khamraev, 2016).

In the other words, this dialogue shows the widespread rejection throughout the general public of historic facts in favor of legend. The explanation of this phenomenon, again, lies in the area of myth rather than logic and rationality. Moreover, the journalist pays no attention to the real soldiers; the whole regiment was involved and more than 100 soldiers were killed. He says "the feat is the feat, no matter if the reporters embellished or embroidered the story." S. Mironenko responded in saying: "Most grievous problem of the Soviet Union was that fictitious heroes seemed to be much more important than the real ones" (ibid.).

Thereby, Sergey Mironenko's interview marked the beginning of the period when "legend" is replacing "fact," and the period when political myth starts domineering in the field of historical sciences.

In June, 2016, the State Archive published the referenced report on the case of 28 soldiers of General Panfilov on its web-site. The author of the digitalized document issued on May 10, 1948, was Chief Military Prosecutor Nikolay Afanasiyev, who came to the conclusion that "the feat of 28 Panfilov's guardsmen is fictional" (State Archive of the Russian Federation, 2016). At the same time, the author of the report had to state that the memory of these soldiers had been already perpetuated in a large number of schools, factories, and collective farms of the Soviet Union. Now even historic document contains the seeds of myth since its author has no intention to suggest any variant of renaming it.

The seeds of myth were planted in 1945, sprouting in 1975 when the great memorial devoted to the "Feat of the 28 " was erected near Dubosecovo. The majestic memorial of six colossal statues made of grey granite symbolizes the six nationalities represented in the famous regiment. Six titanic figures wearing long greatcoats were intended to have a resemblance with the epic warriors (bogatyrs). Thus, the idea of the sacred defenders of Moscow was embodied in stone.

On October 4, 2016, the Minister of Culture Vladimir Medinsky commented on the issue of Panfilov's 28 soldiers, saying that "this is a sacred legend that cannot be touched." $\mathrm{He}$ also added that even discussion on the theme is "blasphemy." The Minister called the feat "symbolical" and put it with the same rank as " 300 Spartans." It seems that the Minister referred to Zack Snyder's famous film 300 Spartans (2006), and probably to its 2014 
sequel with an even more specific title of 300 Spartans: The Rise of an Empire. The Minister stated: “This is the legend. Were there $28,30,38$, even 48 of 130 soldiers? We don't know. And nobody knows. And nobody will have ever known. And there is no reason in trying to know it" (RIA Novosti, 2016a).

It is also necessary to note that the screening of the film 28 Panfilovtsev (Panfilov's Twenty-Eight) followed the meeting of President V. Putin and President N. Nazarbayev (RIA Novosti, 2016b). Officially, the film came out on November 24, 2016.

Such statements demonstrate a significant point in the reception of historical facts. The use of such words as "legend," "sacred," "blasphemy," and symbolical' can be considered as a part of the ideologically-marked process of sacralization in the fields of social and cultural discourse.

Similar expressions such as "legend," "feat," "memorial," and "symbol" can be seen on the film's web site. Moreover, there is a contradistinction between the feat and its dethronement, known as "undermining." The text actually says: "Today, any adolescent who Googles 'Panfilov's Twenty-Eight' will find articles-laden with 'facts'-about how and why the myth of the 28 soldiers who stopped the German tanks was fabricated" (Panfilov's 28 Men, 2016). The text contains the widely-used opposition of "us" and "them": "In the $21^{\text {st }}$ century, the tide of historical 'truth' has turned away from the heroes." Putting the word "truth" in double quotation marks means that history is gradually transformed into a kind of sacred structure and part of the "spiritual bonds" mentioned in 2012.

The case of Panfilov's Twenty-Eight indicates a perfect myth according to Roland Barthes's conception; the current ideology transfigures the meaning of a sign whereas the form remains untouched. Hence, the form is the existence of the soldiers of General Panfilov's regiment who defended Moscow at the Dubosekovo crossroads. The primal meaning, in its turn, is that the reporter invented the story where 130 fallen defenders was reduced to 28 in the article for the front-line newspaper. The secondary, ideological meaning is that the article has become a sacred text, and those who cast doubts and question the details are renegades.

Indeed, the form of historic fact that can be discussed and examined is filled with rather different meanings of sacred legends. Moreover, the whole story becomes a part of a new mythology.

As well, the famous words allegedly said by Klochkov the political commissariat of "We have nowhere to retreat. Moscow is behind us" actually represents a famous literal allusion to Mikhail Lermontov's "Borodino" (1837). Lermontov wrote (2016):

And eyes aflame, he spoke his mind:

"Hey lads! is Moscow not behind?

By Moscow then we die

As have our brethren died before!

And that we'll die we all then swore,

And th' oath of loyalty ne'er tore

Neath Borodinian sky. ${ }^{7}$ 
It is obvious that either or both the reporter Koroteev and the literary editor Krivtsov referred consciously or subconsciously to the epic theme of the Patriotic War of 1812, as well as to its well-known reflections in Russian literature. By that time, "Borodino," and especially the recognizable quotation "Hey lads! is Moscow not behind?", had become the part of the literature curricula in Soviet schools. "Borodino" was used as a perfect example of patriotism. This was mostly due to the poetic tone of the text where the heroic past is opposed to the un-heroic present. Lermontov expresses it in the refrain: "The men in my time weren't like this weak folk-bogatyrs they were, as you are not."

\section{Conclusion}

The term of political myth today must not be restricted within the narrow limits of narration and plot. Even "discourse" cannot be considered as a synonym. Today, political myth constitutes a new area connected with the categories of semiotics, beliefs, and power. Moreover, political myth uses the meme as a part of social media to shape its own reality, in human minds as well as in the media. The most wide-spread political myths in Russia broadcast the same message of sacred historic glory, where the past takes precedence over the present (and the future).

Three political myths, those of the "Fallen Empire", of the "Polite People" and of "Panfilov's Twenty Eight," reveal different dimensions of the same system. This system ideologically possesses historical categories and transforms them into a secondary reality that can exist only in the sphere of the media.

Thus, the Fall of the Byzantium Empire has a mass culture alternative of the Night Wolves bike show "The Fifth Empire," and is extension and cultural back-up at the same time. The memetic instrument for it is the "spiritual bonds" meme.

The "Polite People" case is even more representative, as the meme appeared spontaneously, and was immediately built into the already-existing chronotope model of the Heroic Past (or Dream Time). One of the hidden ideological messages is time looping: the Soviet Past and Soviet glory is the same as present-day heroism.

The "Polite People" myth has its continuation in the myth of "Panfilov's Twenty Eight." The memetic instrument is the "sacred past" in the sphere of public discussion. The category of the historical past is again dissolved in the secondary reality of myth. Moreover, historical facts are denied and despised in favor of a mass culture product, the film having been released in November, 2016.

All three examples illustrate the same attitude of the establishment to the issues of "spiritual bonds" and the "sacred past," which is the creation of an invented reality designed to be believed. There is no realistic time frame; it is replaced with a "heroic dream time" that is indisputable. Today, the glory of the Past seems to be mostly a reflection of Soviet glory. 


\section{References}

Bakhtin M. (200o) Jepos i roman [Epos and the Novel], Saint Petersburg: Azbuka.

Bakhtin M. (2004) Forms of Time and of the Chronotope in the Novel. The Dialogic Imagination, Austin: University of Texas Press, pp. 84-258.

Barthes R. (1991) Mythologies, New York: The Noonday Press.

Bemong N., Borghart P., Dobbeleer M. De, Demoen K., Temmerman K. De, Keunen B. (2010) Bakhtin's Theory of the Literary Chronotope: Reflections, Applications, perspectives, Gent: Academia Press.

Budaragin M. (2012) "Sejchas rozhdaetsja Pjataja imperija" ["The Fifth Empire Is Being Born Right Now"]. Available at: http://vz.ru/politics/2012/8/23/594683.html (accessed 21 November 2016).

Bottici Ch. (2007) A Philosophy of Political Myth, Cambridge: Cambridge University Press.

Cassirer E. (1953) Language and Myth, New York: Dover.

Cassirer E. (1973) The Myth of the State, New Haven: Yale University Press.

Cohen T. (1998) Ideology and Inscription: "Cultural Studies" after Benjamin, De Man, and Bakhtin, Cambridge: Cambridge University Press.

Dremova N. (2016) "Pjataja imperija” Hirurga. Bajker o lichnoj vojne, sankcijah i sud'bah Rossii [Surgeon's “Fifth Empire." The Famous Biker Speaks on the Personal War, Sanctions, and Destinies of Russia]. Available at: http://www.krym.aif.ru/society/pyataya_ imperiya_hirurga_o_lichnoy_voyne_sankciyah_i_kovrike_pered_dveryu (accessed 10 August 2016).

Fairclough N. (2001) The Dialectics of Discourse. Textus, vol. 14, no 2, pp. 231-242.

Flanagan M. (2009) Bakhtin and the Movies: New Ways of Understanding Hollywood Films, London: Palgrave Macmillan.

Flood C. G. (2013) Political Myth: A Theoretical Introduction, London: Routledge.

Frye N. (1982) The Great Code, New York: Harcourt Brace Jovanovich.

Kalinin I., Khokhryakova S. (2014) Kak sozdavalsja gimn "Vezhlivye ljudi": otkrovenija avtorov [How the Hymn "Polite People" Was Created: Revelations by the Authors]. Available at: http://www.mk.ru/politics/article/2014/o4/23/1019203-kak-sozdavalsyagimn-vezhlivyie-lyudi-otkroveniya-avtorov.html (accessed 30 October 2016).

Khamraev V. (2016) Razoblachenie fal'sifikatora i izgotovlennoj im fal'shivki neizbezhno [Disclosure of the Forger and His Fake Is Inevitable]. Available at: http://kommersant. $\mathrm{ru} /$ Doc/2712788 (accessed 20 October 2016).

Lasswell H. (1966) The Analysis of Political Behavior: An Empirical Approach, London: Routledge \& Kegan Paul.

Lasswell H., Kaplan A. (1950) Power and Society: A Framework for Political Inquiry, New Haven: Yale University Press.

Lermontov M. (2016) Borodino. Available at: http://www.borodino.hrest.info/borodinoen-text.htm (accessed 30 September 2016). 
Lull J. (2008) Media, Communication, Culture: A Global Approach, Cambridge: Polity Press.

Lynch A. (1996) Thought Contagion: How Belief Spreads through Society, New York: Basic Books.

Matveeva O., Melik-Gaikazyan I. (2005) Mif i utopija: dve storony mechty [Myth and Utopia: Two Sides of Dream]. Mif, mechta, real'nost': postneklassicheskie izmerenija prostranstva kul'tury [Myth, Dream, Reality: Postnonclassic Dimensions of Cultural Space] (ed. I. Melik-Gaikazyan), Moscow: Nauchny mir, pp. 162-175.

McLuhan M. (1994) Understanding Media: The Extensions of Man, New York: McGrawHill.

Meduza (2016) Pjataja imperija i okamenevshie sklepy [The Fifth Empire and the Fossilized Crypts]. Available at: https://meduza.io/shapito/2016/o8/17/pyataya-imperiya-iokamenevshie-sklepy (accessed 17 Ocotber 2016).

Nielsen G. M. (2002) The Norms of Answerability: Social Theory between Bakhtin and Habermas, Albany: State University of New York Press.

Panfilov's 28 Men (2016) Available at: http://28panfilovcev.com/en/about.php (accessed 11.11. 2016)

Putin V. (2012) Poslanie Federal'nomu Sobraniju. 12 dekabrja 2012 [Address to the Federal Assembly, December 12, 2012]. Available at: http://kremlin.ru/events/president/ news/17118 (accessed 11 December 2016).

RIA Novosti (2016a) Medinsky nazval "konchenymi mrazjami” somnevajushhihsja v podvige panfilovcev [Medinsky Called Those Who Doubt the Feat of Panfilov's Men "Complete Scum"]. Available at: https://ria.ru/society/20161004/1478502045.html (accessed 4 December 2016).

RIA Novosti (2016b) Putin i Nazarbaev posle foruma v Astane posmotreli fil'm " 28 panfilovcev" [The Film "Panfilov's 28 Men" Was Shown to Putin and Nazarbaev after the Forum]. Available at: https://ria.ru/world/20161004/1478485516.html (accessed 4 December 2016).

Rozhin B. (2014) Krym-o proishozhdenii mema pro "vezhlivyh ljudej" [Crimeaabout the Origin of the "Polite People" Meme]. Available at: http://www.iarex.ru/articles/46396.html (accessed 23 November 2016).

Shevchenko V. (2014) "Little Green Men" or "Russian Invaders"? Available at: http://www. bbc.com/news/world-europe-26532154 (accessed 11 November 2016).

Shevkunov T. (2008) The Text of the Film "The Fall of an Empire: The Lesson of Byzantium”. Available at: http://vizantia.info/docs/27.htm (accessed 11 October 2016).

Shteynman M. (2014) Politiko-kommunikativnye reprezentacii fil'ma D. Rajta "Anna Karenina” v sovremennoj Rossii [“Anna Karenina” by J. Wright and Its Political and Communicative Representations in Present-Day Russsia]. RSUH/RGGU Bulletin, vol. 123, no 1, pp. 285-295.

Sindelar D. (2015) Russia Unveils Monument to "Polite People" behind Crimean Invasion. Available at: http://www.rferl.org/a/russia-monument-polite-people-crimeainvasion/27000320.html (accessed 7 December 2016). 
Skibina E. (2014) Shoigu o “zelenyh chelovechkah” na Ukraine: glupo iskat' chernuju vezhlivuju koshku v temnoj komnate [Shoigy about the "Little Green Men" in Ukraine: It Is Foolish to Look for a Black and Polite Cat in the Dark Room]. Available at: http://www.mk.ru/politics/russia/article/2014/o4/17/1016052-shoygu-o-zelenyihchelovechkah-na-ukraine-glupo-iskat-chernuyu-vezhlivuyu-koshku-v-temnoykomnate.html (accessed 17 October 2016).

State Archive of the Russian Federation (2016) Spravka-doklad glavnogo voennogo prokurora N. Afanas'eva "O 28 panfilovcah" [The Inquiry Report "On the Case of 28 Soldiers of General Panfilov" by the Chief Military Prosecutor Nikolay Afanasiev]. Available at: http://statearchive.ru/607 (accessed 30 October 2016).

Sungrurov A. (2003) Hronotop kak instrument regional'nogo politicheskogo analiza [Chronotope as a Tool for Regional Political Analysis]. Political Studies, no 6, pp. 6270.

Tudor H. (1973) Political Myth, London: Macmillian.

Wodak R., Rudolf R. M., Liebhart K. (1999) The Discoursive Construction of National Identity, Edinburgh: Edinburgh University Press.

\title{
Политический миф о славе: создание медиареальности
}

\author{
Мария Штейнман \\ Кандидат филологических наук, доцент кафедры теории и практики общественных связей факультета \\ истории, политологии и права Российского государственного гуманитарного университета \\ Адрес: Миусская площадь, д. 6, ГСП-3, Москва, Российская Федерация 125993 \\ E-mail: philology@mail.ru
}

В настоящий момент наблюдаются серьезные изменения в социокультурном пространстве. В первую очередь, речь идет о процессе проникновения в него особых семиотических конструктов. Их можно описать как политические мифы. И значительная их часть тесно связана с концепцией славы (прежде всего, государственной) - как в прошлом, так и в настоящем и будущем времени. Эта слава может рассматриваться как утерянная (развал СССР) или же возрожденная (вхождение Крыма в состав Российской Федерации в 2014). Концепции славы и победы (прежде всего, победы в Великой Отечественной войне) настолько тесно связаны в российском политическом дискурсе, что все заметнее становится процесс своего рода их присвоения истеблишментом. Понятие политического мифа давно вышло за рамки нарратива, и теперь особое значение приобретает его семиотическая структура. Миф представляет собой знак, трансформированный идеологией, и, с другой стороны, является актором, который создает (или, по меньшей мере, трансформирует) социокультурную реальность вокруг себя. В качестве инструмента здесь выступает мем, который укоренен в сфере медиа. При этом организации пространства мифа, как правило, соотносится с понятием хронотопа, предложенным М. Бахтиным. В современном российском политическом дискурсе содержится три доминирующих политических мифа, активно апеллирующих к концепту славы. Во-первых, это миф о Византийской империи и утраченной славе, которой противопоставляется так называемая «Пятая империя». Во-вторых, речь идет 
о мифе о «вежливых людях», при создании которого был задействован соответствующий мем. Наконец, особое место занимает миф о двадцати восьми героях-панфиловцах.

Ключевые слова: политический миф, мифологема, мифология, хронотоп, мем, медиа реальность, история, идеология 